\title{
CULTURAL AND SOCIAL
}

\section{ANTHROPOLOGY STUDIES}

IN LATVIA AND EASTERN EUROPE:

DISCUSSING PRACTICES AND METHODS

In the last academic year, two international scientific conferences were held in Riga, focusing on the anthropological dimension in the field of social sciences.

Baltic International Academy (Riga, Latvia) in cooperation with the Institute of Ethnology and Folklore Studies with Ethnographic Museum of the Bulgarian Academy of Sciences (Sofia, Bulgaria), the Ural Federal University (Ekaterinburg, Russian Federation), the University of Oradea (Oradea, Romania) and the International Festival of Visual Anthropology Mediating Camera (Moscow, Russian Federation) organised an international scientific conference Social and Political Anthropology: Modern Scientific Approaches to Research ${ }^{1}$ (Riga, 18-19 October, 2019).

Researchers from Bulgaria, Latvia, Romania and Russia took part in the conference and discussed methodological aspects in the field of social and political anthropology drawing attention to certain phenomena, for example, xenophobia in Central and Eastern Europe in the context of the refugee crisis (the paper by Romanian researcher Dr. Edina Lilla Meszaros) or discursive practices in the inter-ethnic communication in Latvia (the paper by Latvian researcher Dr. Vladislav Volkov). One section of the conference was dedicated to the interdisciplinary approach in the study of cultural heritage and cultural practices. The papers for the section were offered by the specialists of various fields, whose research interests concerned the intersections of cultural identity, cultural heritage and cultural practices. Among the speakers, there was Bulgarian anthropologist Dr. Ekaterina Anastasova, who presented her research on the transformations of the sacred space in Bulgaria and in the Baltics at the turn of the $20^{\text {th }}$ and $21^{\text {st }}$ centuries, as well as Russian historian Dr. Elena Danilko, the initiator and the director of the only festival of anthropology in Russia Mediating Camera, offering an overview of the research tradition in the visual 
anthropology. Latvian scholars dedicated their presentations on the issues of documentation and interpretation of the "complicated past". Historian Dr. Inese Runce examined the position of the Catholic Church in Latvia occupied by the Nazis (1941-1944), whereas philosopher Dr. Solveiga Krūmina-Koṇkova shared her reflections on the opportunities to use criminal cases initiated by the Soviet security services as an example of historical sources and discursive practice. Cultural sociologist Dr. Nadežda Pazuhina examined the photo archives of Latvian Old Believers as a specific practice of documentation and self-representation. The conference programme can be found here: https:// bsa.edu.lv/en/1197/.

The Institute of Philosophy and Sociology of the University of Latvia and the Institute of Latvian History of the University of Latvia in cooperation with the Social and Political Critique Centre \& Philosophy Department, Vytautas Magnus University and the Institute of Political Science and Public Administration, University of Zielona Góra organized scientific conference Anthropology of political, social and cultural memory: practices in Central and Eastern Europe (Riga, 13-14 March, 2020) ${ }^{2}$. The event took place within the framework of project Interaction between the individual, the society and the state in process of the history of Latvia: conflicting values and formation of shared values during historical turning points under the National Research Programme Latvian Heritage and Future Challenges for the Country's Sustainability.

On the first day of the conference, session Legacy of the Interwar Period in the Republic of Latvia and its Preservation During the Occupation was focused on the historical evidence in terms of how the change of values took place in the circumstances of the occupation regimes of the mid- $20^{\text {th }}$ century - both Soviet and the Nazis, how and what means were used to preserve the interwar legacy. Historian Dr. Daina Bleiere described the Soviet education policy in a comprehensive way with regard to the ideological interpretation of Latvia's interwar period in the school curricula, whereas ethnologist Dr. Anete Karlsone analysed the transformations of Latvian folk costume in the framework of Soviet ideological context comparing the understanding of "folkness" and its political representation during the authoritarian regime of Kārlis Ulmanis. Historian Dr. Inese Runce turned to the analysis of a diary of the outstanding figure of the Latvian Catholic Church - Cardinal Julijans Vaivods revealing the tension between the individually subjective retrospection and the imprint of the political discourse. 
The presenters of the second day of the conference from Latvia, Lithuania, Poland, the Czech Republic and Russia discussed the outcomes of the current studies that were related to the perception and commemorative practices of the shared past, as well as the reciprocity of the political practices and cultural memory and the conceptualisation of the individual and collective memory (and commemoration). Several papers were dedicated to the national, regional and cultural identity building processes from the perspective of social and political anthropology. Czech historian Dr. Zdenko Maršálek examined the transformations of collective identity of Silesian population in the context of political events and ideological impacts, whereas Latvian historian Dr. Mārtiņš Mintaurs analysed the ideas on Latvian national identity at the turn of the $19^{\text {th }}$ and $20^{\text {th }}$ centuries under the influence of social and economic modernisation processes. Furthermore, Polish historian Aleksei Rogozin characterised the specific identity of the inhabitants living in Warsaw and Riga suburbs, as well as urban cultural practices. He was followed by reflections on the memorial and commemorative practices and their discursive manifestations. Latvian philosopher Dr. Igors Šuvajevs described the practice of forgetting in culture providing an opportunity to stage various versions of the past facilitating or restricting the "remembering" in the public space. The theme of traumatic memories was continued by Russian philosopher Dr. Ludmila Artamoshkina, whereas the presence of latent and non-rationalised past in biographical stories was examined by Latvian cultural sociologist Dr. Nadežda Pazuhina. The discursive manifestations of the identity were investigated by Latvian sociologist Dr. Vladislavs Volkovs. The global pandemic situation added another anthropological dimension to the conference requiring adaptation to the new situation and thinking of new formats of academic communication. These are the challenges that we all still need to take into account in our everyday lives. The conference programme and theses are available here: https://dspace.lu.lv/ dspace/handle/7/50099.

Nadežda Pazuhina

\section{Notes}

1 October 18-19, 2019 (Riga, Latvia) Social and Political Anthropology: Modern Scientific Approaches to Research Conference organizers: Baltic International Academy 
(Riga, Latvia), Institute of Ethnology and Folklore Studies of the Bulgarian Academy of Sciences (Sofia, Bulgaria), Ural Federal University (Ekaterinburg, Russian Federation), University of Oradea (Oradea, Romania), International Festival of Visual Anthropology "Mediating Camera" (Moscow, Russian Federation).

2 Anthropology of political, social and cultural memory: practices in Central and Eastern Europe. Institute of Philosophy and Sociology, University of Latvia; Institute of Latvian History, University of Latvia; Social and Political Critique Centre \& Philosophy department, Vytautas Magnus University; Institute of Political Science and Public Administration, University of Zielona Góra.

Nadežda Pazuhina, Dr. Art, Senior Researcher at the Institute of Philosophy and Sociology of the University of Latvia, Assistant Professor at the Baltic International Academy (Riga). Research fields: history and culture of the Orthodox Old Believers, Russian Orthodox Church and Ecumenism Movement in the Baltic States, history of Russian minority in Latvia, theoretical approaches to studying religion and culture. 